\title{
Pengaruh Bagian Organ dan Persentase Ekstrak Tanaman Kayu Putih (Melaleuca leucadendra L.) terhadap Perkecambahan Benih Jagung (Zea mays) dengan Metode Bioassay
}

Syprianus Ceunfin ${ }^{\mathrm{a}}$

${ }^{a}$ Fakultas Pertanian, Universitas Timor, Kefamenanu, TTU - NTT, Indonesia.

\section{Article Info}

Article history:

Received 6 April 2018

Received in revised form 21 Januari 2019

Accepted 14April 2019

$D O I:$

https://doi.org/10.32938/sc.v4i02.275

\section{Keywords:}

Bagian Organ

Persentase Ekstrak

Kayu Putih

Benih Jagung

Bioassay

\begin{abstract}
Abstrak
Produksi tanaman Jagung akhir-akhir ini terus mengalami penurunan. Hal ini sebagai akibat dari pergeseran pemanfaatan lahan-lahan produktif menjadi lahan tidak produktif. Oleh karena itu, tumpangsari menjadi salah satu alternatif produksi bahan pangan. Lahan yang paling berpotensi untuk menanam tanaman pangan adalah hutan produksi berbasis kayu putih. Penelitianini bertujuan untuk mengetahui pengaruh bagian organ dan persentase ekstrak tanaman Kayu Putih terhadap perkecambahan benih Jagung dengan metode bioassay serta menentukan tingkat ketahanan kecambah terhadap alelopati. Penelitian dilaksanakan pada bulan Maret-Mei 2015 di Bangun Tapan, Bantul Yogyakarta. Rancangan yang digunakan dalam penelitian ini adalah Rancangan Acak Lengkap (RAL) Faktorial.Faktor pertama adalah bagian organ tanaman (E) yang digunakan sebagai ekstrak, terdiri dari 9 aras yaitu ekstrak akar zona 1, ekstrak akar zona 2, ekstrak kulit batang, ekstrak daun segar, ekstrak serasah daun, ekstrak akar zona $1+$ ekstrak kulit batang + ekstrak daun segar + ekstrak serasah, ekstrak akar zona 2 + ekstrak kulit batang + ekstrak daun segar + ekstrak serasah,ekstrak kulit batang + ekstrak daun segar + ekstrak serasah,ekstrak daun segar + ekstrak serasah daundan faktor kedua adalah konsentrasi ekstrak yang terdiri dari 6 level yaitu kontrol,ekstrak $20 \%$, ekstrak $40 \%$, ekstrak $60 \%$, ekstrak $80 \%$, ekstrak $100 \%$ dengan ukuran $10 \mathrm{~mL}$. Terdapat 54 kombinasi perlakuan masing-masing diulang 3 kali sehingga total unit penelitian adalah 162 nampan. Variabel pengamatan dalam penelitian ini adalah menghitung vigor benih dan stress tolerance index pada vigor benih. Hasil penelitian menunjukkan bahwa tidak terjadi interaksi antara perlakuan bagian organ tanaman dan persentase ekstrak kayu putih terhadap perkecambahan benih Jagung, seluruh bagian organ segar tanaman kayu putih pada berbagai konsentrasi mampu menghambat pertumbuhan dan perkembangan kecambah dan menempatkan kecambah jagung pada level moderat sampai rentan dalam pengelompokan stress tolerance index.
\end{abstract}

\section{Pendahuluan}

Produksi tanaman jagung akhir-akhir ini terus mengalami penurunan.Ha ini sebagai akibat dari pergeseran pemamfaatan lahan-lahan produktif menjadi lahan tidak produktif. Oleh karena itu tumpangsari menjadi salah satu alternatif produksi bahan pangan. Lahan yang paling berpotensi untuk menanam tanaman pangan adalah hutan produksi berbasis kayu putih.Hutan kayu putih sangat cocok digunakan sebagai lahan produksi pangan karena selalu dipangkas daunnya.Walaupun sering dipangkas tanaman kayu putih diketahui mengandung miyak atsiri sehingga berpotensi untuk menghambat perkecambahan tanaman semusim semakin terbuka. Minyak atsiri merupakan salah satu produk dari senyawa kimia. Junai di danYunus (2009), menyatakan bahwa tanaman kayu putih mengandung senyawa kimia masing-masing adalah a-selulosa $37 \%$, holoselulosa $75,39 \%$, lignin $22,85 \%$, pentosan $18,85 \%$, zat ekstraktif 4,58\% dan abu 0,92\%. Rahim (2010), daun kayu putih mengandung bahan kimia sebagai berikut: pinene,b-pinene, myrcene, a-terpinene, limonene, 1,8-cineole, y-terpinene, p-cymene,terpinolene, linalool, terpinen-4-ol danterpineol. Bahan kimia tersebut merupakan turunan dari senyawa fenolik flavonoid, $\alpha$-tokoferol dan karoteniod.

Senyawa-senyawa kimia yang dimiliki oleh kayu putih ini memiliki kemampuan menghambat pertumbuhan tumbuhan atau tanaman sasaran yang berada disekitar, sebagai interaksi langsung antar spesies yang disebut alelopati.Alelopati didefinisikan sebagai suatu fenomena alam dimana suatu organisme memproduksi dan mengeluarkan suatu senyawa biomolekul ke lingkungan dan senyawa tersebut mempengaruhipertumbuhan dan perkembangan organisme lain di sekitarnya (Junaedi et al., 2006). Alelopati merupakan pelepasan senyawa bersifat toksik yang dapat mengganggu pertumbuhan tanaman disekitarnya dan senyawa yang bersifat alelopati disebut alelokimia (Kurniasih,2002), selanjutnya menurut Junaedi et al., (2006), alelopati memberikan pengaruh langsung maupun tidak langsung dari suatu tumbuhan terhadap tumbuhan lainnya, baik yang bersifat positif maupun negatif melalui pelepasan senyawa kimia ke lingkungannnya. Alelopati merupakan proses yang melibatkan metabolik sekunder yang dihasilkan oleh tanaman, algae, bakteri dan fungi yang berpengaruh terhadap pertumbuhan dan perkembangan sistem pertanian dan biologi (Djazuli dan Sukamto, 2011).

Alelopati pada tumbuhan dibentuk di berbagai organ, seperti akar, batang, daun, bunga dan atau biji. Organ pembentuk dan jenis alelokimia bersifat spesifik pada setiap spesies. Alelopati adalah produk dari metabolisme sekunder dan metabolit primer non-gizi, yang digolongkan menjadi 14 golongan yaitu: asam organik larut air, lakton, asam lemak rantai panjang, quinon, terpenoid, flavonoid, tanin, asam sinamat dan derivatnya, asam benzoat dan derivatnya, kumarin, fenol dan asam fenolat, asam amino nonprotein, sulfida nukleosida. Setiap bagian organ tanaman mengandung alelopati namun konsentrasinya berbeda-beda.Oleh karena itu telah dilakukan penelitian pada berbagai tumbuhan maupun tanaman berpotensi alelopati dari konsentrasi rendah sampai dengan konsentrasi tinggi terhadap tanaman-tanaman sensitif. Setyowati et al., (1999), konsentrasi $30 \mathrm{~g} / \mathrm{L}$ daun teki sebagai sumber alelopati mampu menghambat perkecambahan jagung. Gulma babandotan dan kirinyu dengan konsentrasi $50 \mathrm{~g} / \mathrm{L}$ mampu menekan pertumbuhan kecambah biji sawi (Togatorop et al., 2010). Fitria (2011), pemberian ekstrak gulma dengan konsentrasi $40 \mathrm{~g} / \mathrm{L}$ hingga $120 \mathrm{~g} / \mathrm{L}$ mampu menurunkan bobot buah total per tanaman pada tanaman tomat. Cairan perasan daun A.conyzoides pada konsentrasi $100 \mathrm{~g} / \mathrm{L}$ sudah mampu menghambat perkecambahan, bahkan pada konsentrasi $500 \mathrm{~g} / \mathrm{L}$ mampu menghambat perkecambahan 100\% (Hafsah et al., 2012). Alelopati mempengaruhi pertumbuhan tanaman melalui penghambatan penyerapan hara yaitu dengan menurunkan kecepatan penyerapan ion-ion oleh tumbuhan, menghambat pembelahan sel-sel akar tumbuhan, menghambat pertumbuhanyaitudengan mempengaruhi pembesaran sel tumbuhan, menghambat respirasi akar, menghambat sintesis protein, menurunkan daya permeabilitas membran pada sel tumbuhan dan menghambat aktivitas enzim (Djazuli, 2011).Pengaruh alelokimia (khususnya yang menghambat) terhadap pertumbuhan dan perkembangan organisme (khususnya tumbuhan) sasaran melalui serangkaian proses yang cukup kompleks, namun proses tersebut diawali pada membran plasma dengan terjadinya kekacauan struktur, modifikasi saluran membran, atau hilangnya fungsi enzim ATP-ase. Hal ini akan berpengaruh terhadap penyerapan dan konsentrasi ion dan air yang kemudian mempengaruhi pembukaan stomata dan proses fotosintesis. Hambatan berikutnya mungkin terjadi dalam proses sintesis protein, pigmen dan senyawa karbon lain, serta aktivitas beberapa fitohormon. Sebagian atau seluruh hambatan tersebut kemudian bermuara pada terganggunya pembelahan dan pembesaran sel yang akhirnya menghambat pertumbuhan dan perkembangan tumbuhan sasaran (Nandito, 2006).

Penelitian ini bertujuan untuk mengetahui pengaruh bagian organ dan persentase ekstrak tanaman kayu putih terhadap perkecambahan benih jagung dengan metode bioassay serta menentukan tingkat ketahanan kecambah terhadap alelopati.

\section{Metode}

Penelitian dilaksanakan pada bulan Maret-Mei 2015 di Bangun Tapan, Bantul, Yogyakarta. Rancangan yang digunakan dalam penelitian ini adalah rancangan acak lengkap (RAL) faktorial. Faktor pertama adalah bagian tanaman (E) yang digunakan sebagai ekstrak, terdiri dari 9 aras yaitu ekstrak akar zona 1(E1), Ekstrak akar zona 2 (E2) ekstrak kulit batang (E3), ekstrak daun segar (E4), ekstrak serasah daun (E5), ekstrak akar zona $1+$ ekstrak kulit batang + ekstrak daun segar + ekstrak serasah (E6), ekstrak akar zona $2+$ ekstrak kulit batang + ekstrak daun segar + ekstrak serasah (E7),ekstrak kulit batang + ekstrak daun segar + ekstrak serasah (E8), ekstrak daun segar + ekstrak serasah daun (E9), dan faktor kedua adalah konsentrasi ekstrak (K) yang terdiri dari 6 level yaitu $\mathrm{K}_{0}$ : kontrol (aquades $100 \%$ dengan ukuran 10 $\mathrm{mL}), \mathrm{K}_{1}$ : Ekstrak $20 \% ; 2$ mLekstrak $+8 \mathrm{~mL}$ aquades, $\mathrm{K}_{2}::$ Ekstrak $40 \% ; 4$ mLekstrak $+6 \mathrm{~mL}$ aquades, $\mathrm{K}_{3}$ : Ekstrak $60 \% ; 6 \mathrm{~mL}$ ekstrak $+4 \mathrm{~mL}$ aquades, K4:: Ekstrak $80 \% ; 8 \mathrm{~mL}$ ekstrak $+2 \mathrm{~mL}$ aquades, $\mathrm{K}_{5}$ : Ekstrak $100 \%$ dengan ukuran $10 \mathrm{~mL}$. Terdapat 54kombinasi perlakuan masing-masing diulang $3 \mathrm{kali}$ +3 (kontrol) sehingga total unit penelitian adalah 162 plot.

Bahan baku yang telah disiapkan ditimbang sebanyak $100 \mathrm{~g}$, dibersihkan dari tanah atau kotoran lain. Bahan-bahan tersebut dipotong kecil-kecil menggunakan parang atau golok, kemudian dihancurkan menggunakan blender secara terpisah. Setelah semua bahan hancur direndam dalam $100 \mathrm{~mL}$ aquades selama 24 jam, kemudian ekstrak disaring dan ditampung dalam wadah yang bisa ditutup rapat dan ekstrak siap untuk digunakan (Chung dan Miller1995; Solichatun, 2000). Ekstrak yang telah disiapkan diukur menggunakan gelas ukur sesuai dengan perlakuan kemudian diencerkan dengan aquades. Hasil pengenceran dituangkan dalam nampan plastik perlakuan yang telah disiapkan bersama kertas saring. Kemudian benih ditempatkan diatas kertas saring yang telah basah oleh larutan ekstrak. Namun sebelumnya benih telah direndam selama 12 jam agar benih mudah berkecambah. Setiap nampan plastik perlakuan di isi dengan 10 benih jagung. Pengamatan terhadap benih yang telah ditanam pada hari ke 1 setelah tanam sampai pada hari ke 7 setelah tanam. 


\section{Variabel Pengamatan}

Variabel pengamatan dalam penelitian ini adalah menghitung vigor benih dengan mengamati beberapa variabel pendukung kekuatan berkecambah seperti: panjang plumula, panjang akar dan bobot kering total kecambah.

1. Panjang Plumula $(\mathrm{cm})$

Panjang plumula dihitung dengan cara mengukur tunas kecambah mulai dari pangkal akar sampai dengan ujung daun terpanjang menggunakan mistar kemudian angkanya dicatat. Panjang plumula diukur pada 10 sampel kecambah jagung, kemudian dirata-ratakan untuk memperoleh panjang plumula setiap kecambah.

2. Panjang Akar (cm)

Panjang akar dihitung dengan cara mengukur tunas kecambah mulai dari pangkal akar sampai dengan ujung akar terpanjang menggunakan mistar kemudian angkanya dicatat. Panjang akar diukur pada 10 sampel kecambah jagung kemudian dirata-ratakan untuk memperoleh panjang akar setiap kecambah.

3. Bobot Kering Kecambah (g)

Bobot kering kecambah diukur menggunakan timbangan analitik kemudian dicatat angkanya.Berat kering kecambah diukur pada 10 sampel kecambah jagung kemudian dirata-ratakan untuk memperoleh berat setiap kecambah.

4. Stress Tolerance Index (STI) vigor benih

Cekaman adalah keadaan tanaman mengalami gangguan dari faktor luar yang tidak menguntungkan bagi tanaman dan memiliki pengaruh buruk terhadap pertumbuhan, produksi maupun kelangsungan hidup dari tanaman (Fallah, 2006). Untuk mengetahui suatu individu mengalam cekaman pada saat perkecambahan dapat dihitung dengan menggunakan persamaan STI menurut Fernandez (1993), kemudian dilakukan pengelompokan tingkat ketahanan kecambah terhadap STI berdasarkan nilai rerata dan nilai standar deviasi sebagai berikut:

$\mathrm{T}=$ Tahan

$>$ rerata seluruh perlakuan + standar deviasi

$\mathrm{AT}=$ Agak Tahan

$<$ rerata seluruh perlakuan + standar deviasi sampai de-ngan $>$ rerata seluruh perlakuan $+1 / 2$ standar deviasi

$\mathrm{M}=$ Moderat $/$ sedang

$<$ rerata seluruh perlakuan $+1 / 2$ standar deviasi sampai dengan $>$ rerata seluruh perlakuan $-1 / 2$ standar deviasi

$\mathrm{AR}=$ Agak Rentan

$<$ rerata seluruh perlakuan $-1 / 2$ standar deviasi sampai dengan $>$ rerata seluruh perlakuan standar deviasi

$\mathrm{R}=$ Rentan

$<$ rerata seluruh perlakuan - standar deviasi

Data yang akan diperoleh dari hasil pengamatan dianalisis dengan menggunakan analisis varian (Anova) pada taraf $5 \%$ sesuai petunjuk Gomez dan Gomez (1984). Apabila dari analisis varian diperoleh bahwa $F$ hit $>F$ tabel artinya terdapat beda nyata antar perlakuan, untuk itu dilanjutkan dengan uji DMRT (Duncan Multiple Range Test) menggunakan soffware SAS 9.1.

\section{Hasil dan Pembahasan}

Hasil penelitian terhadap benih jagung menunjukkan tidak ada interaksi antara perlakuan jenis ekstrak kayu putih dengan konsentrasi larutan kayu putih. Parameter vigor benih menunjukkan bahwa panjang plumula, panjang akar, dan bobot kering total tanaman saling berbeda nyata pada jenis ekstrak maupun konsentrasi larutan ekstrak kayu putih. Panjang plumula menunjukkan bahwa panjang plumula paling pendek dihasilkan oleh jenis ekstrak daun segar (E4) yang berbeda nyata dengan seluruh perlakuan jenis ekstrak lainnya. Hal ini membuktikan bahwa daun segar tanaman kayu putih memiliki senyawa alelopati lebih tinggi bila dibandingkan dengan bagian lain dari tanaman kayu putih sedangkan pada konsentrasi ekstrak kayu putih menunjukkan bahwa konsentrasi $100 \%\left(\mathrm{~K}_{5}\right)$ ekstrak kayu putih menghasilkan panjang plumula paling pendek yang tidak berbeda nyata dengan konsentrasi ekstrak $60 \%$ dan $80 \%$ tetapi berbeda nyata dengan konsentrasi ekstrak $20 \%$ dan $40 \%$ (Tabel 1 ). Hal ini menunjukkan bahwa berapapun konsentrasi ekstrak kayu putih tetap memberikan efek negatif terhadap pertumbuhan kecambah tanaman jagung sehingga proses fisiologi tanamanpun menjadi terhambat.

Hambatan perkecambahan pada benih disebabkan oleh senyawasenyawa fenol yang terserap kedalam benih dan menghambat metabolisme perombakan endosperm. Masuknya senyawa fenol dapat merusak daya katalisik enzim germinasi terutama hubungannya dengan perombakan karbohidrat (Pramiadi dan Suyitno, 2008). Panjang akar paling pendek dihasilkan oleh perlakuan jenis ekstrak kulit batang tanaman kayu putih $\left(\mathrm{E}_{3}\right)$ yang tidak berbeda nyata dengan perlakuan jenis ekstrak daun segar $\left(E_{4}\right)$.Hal ini menunjukkan bahwa kulit batang tanaman kayu putih juga mengandung alelopati yang mampu menghambat perkecambahan benih terutama terhadap perkembangan akar tanaman jagung, sedangkan konsentrasi $100 \%\left(\mathrm{~K}_{5}\right)$ menghasilkan panjang akar paling pendek yang tidak berbeda nyata dengan konsentrasi $80 \%$, semakin tinggi konsentrasi ekstrak kayu putih semakin kuat pula hambatan yang dialami oleh benih sehingga pertumbuhan akar kecambah menjadi terhambat dan lebih pendek (Tabel 1).
Tabel 1. Vigor Benih Jagung

\begin{tabular}{|c|c|c|c|}
\hline \multirow[b]{2}{*}{ Perlakuan } & \multicolumn{3}{|c|}{ Vigor Benih } \\
\hline & $\begin{array}{c}\text { Panjang } \\
\text { Plumula } \\
\text { (cm) }\end{array}$ & $\begin{array}{c}\text { Panjang } \\
\operatorname{akar}(\mathrm{cm})\end{array}$ & $\begin{array}{l}\text { Berat Kering } \\
\text { Kecambah (g) }\end{array}$ \\
\hline \multicolumn{4}{|l|}{ Jenis Ekstrak } \\
\hline Akar zona 1 (E1) & $12,48 \mathrm{a}$ & $13,86 \mathrm{bc}$ & $0.209 \mathrm{bc}$ \\
\hline Akar zona 2 (E2) & 8,414 bc & $12,94 \mathrm{bc}$ & $0.216 \mathrm{bc}$ \\
\hline Kulit batang (E3) & $7,818 \mathrm{c}$ & $8,346 \mathrm{e}$ & $0.200 \mathrm{bc}$ \\
\hline Daun segar (E4) & $3,049 \mathrm{e}$ & $9,524 \mathrm{de}$ & $0.256 \mathrm{a}$ \\
\hline Serasah (E5) & $11,52 \mathrm{a}$ & $18,739 \mathrm{a}$ & $0.181 \mathrm{c}$ \\
\hline $\mathrm{E} 1+\mathrm{E} 3+\mathrm{E} 4+\mathrm{E} 5(\mathrm{E} 6)$ & $9,701 \mathrm{~b}$ & $14,843 \mathrm{~b}$ & $0.214 \mathrm{bc}$ \\
\hline $\mathrm{E} 2+\mathrm{E} 3+\mathrm{E} 4+\mathrm{E} 5(\mathrm{E} 7)$ & $6,622 \mathrm{~cd}$ & $11,778 \mathrm{~cd}$ & $0.2250 \mathrm{ab}$ \\
\hline E3+E4+E5 (E8) & $5,392 \mathrm{~d}$ & $14,134 \mathrm{bc}$ & $0.203 \mathrm{bc}$ \\
\hline E4+E5 (E9) & $4,896 \mathrm{~d}$ & $15,202 \mathrm{~b}$ & $0.220 \mathrm{abc}$ \\
\hline \multicolumn{4}{|l|}{ Konsentrasi Larutan } \\
\hline $20 \%$ ekstrak : $80 \%$ aquades $(\mathrm{K} 1)$ & $9,4672 \mathrm{a}$ & $14,375 \mathrm{a}$ & $0.19333 \mathrm{~b}$ \\
\hline $40 \%$ ekstrak : $60 \%$ aquades (K2) & $8,033 \mathrm{~b}$ & $14,711 \mathrm{a}$ & $0.21111 \mathrm{ab}$ \\
\hline $60 \%$ ekstrak : $40 \%$ aquades (K3) & $7,578 \mathrm{bc}$ & $13,868 \mathrm{a}$ & $0.21833 \mathrm{ab}$ \\
\hline $80 \%$ ekstrak : $20 \%$ aquades (K4) & $7,466 \mathrm{bc}$ & $11,538 \mathrm{~b}$ & $0.2222 \mathrm{ab}$ \\
\hline $100 \%$ ekstrak : $0 \%$ aquades (K5) & $6,284 \mathrm{c}$ & $11,826 \mathrm{~b}$ & $0.22389 \mathrm{a}$ \\
\hline Interaksi & $(-)$ & $(-)$ & $(-)$ \\
\hline
\end{tabular}

berbeda nyata pada uji DMRT $\alpha=0,05$; (-) : Tidak Terjadi interaksi

Bobot kering total tanaman menunjukkan bahwa kecambah paling berat terdapat pada perlakuan jenis ekstrak daun segar $\left(\mathrm{E}_{4}\right)$ yang tidak berbeda nyata dengan perlakuan $E_{7}$ tetapi berbeda sangat nyata dengan perlakuan jenis ekstrak serasah $\left(\mathrm{E}_{5}\right)$.Hal ini diakibatkan oleh proses perombakan karbohidrat dalam biji terhambat sehingga pemanfaatan karbohidrat dalam biji berjalan lamban, sedangkan pada perlakuan konsentrasi menunjukkan bahwa konsentrasi $100 \%$ menghasilkan bobot kering total kecambah paling berat yang berbeda nyata dengan konsentrasi $20 \%$, hal ini diakibatkan oleh respon benih terhadap proses perkecambahan didalam benih menjadi sangat lamban yang menyebabkan benih masih dalam keadaan utuh sampai akhir penelitian.

\section{STI Vigor Benih Jagung}

Hasil penelitian menunjukkan bahwa tidak terjadi interaksi terhadap parameter STI benih jagung oleh perlakuan jenis ekstrak dan konsentrasi ekstrak kayu putih.Variabel pengamatan terhadap STI panjang plumula benih jagung menunjukkan bahwa perlakuan jenis ekstrak kayu putih yang berasal dari bagian akar zona $1\left(\mathrm{E}_{1}\right)$ lebih tinggi dan tidak berbeda nyata dengan jenis ekstrak yang berasal dari serasah kayu putih $\left(E_{5}\right)$ namun berbeda nyata dengan perlakuan jenis ekstrak kayu putih yang berasal dari daun segar $\left(\mathrm{E}_{5}\right)$ (Tabel 2). Hal ini menunjukkan bahwa pembentukan plumula jagung lebih tahan terhadap cekaman alelopati yang dilepaskan oleh akar kayu putih pada zona 1 dan serasah bila dibandingkan dengan cekaman alelopati yang dilepaskan oleh daun segar. Alelopati yang di lepaskan oleh daun tanaman kayu putih lebih dominan menghambat pembentukan plumula pada benih jagung sehingga pertumbuhan plumula menjadi rentan terhadap cekaman alelopati.

Konsentrasi larutanekstrak kayu putih menunjukkan bahwa konsentrasi $100 \%$ menghasilkan STI panjang plumula paling tinggi yang berbeda nyata dengan konsentrasi larutan $20 \%$. Hal ini membuktikan bahwa dari konsentrasi rendah sampai konsentrasi tinggi larutan kayu putih memiliki zat alelopati yang memberikan pengaruh negatif terhadap pertumbuhan plumula benih jagung dan mengakibatkan tingkat STI pada level sedang pada semua jenis konsentrasi larutan kayu putih (Tabel 2). Variabel pengamatan terhadap STI panjang akar menunjukkan bahwa akar paling pendek dihasilkan oleh perlakuan jenis ekstrak dari kulit kayu putih $\left(\mathrm{E}_{3}\right)$ yang berbeda nyata dengan perlakuan jenis ekstrak serasah $\left(\mathrm{E}_{5}\right)$ kayu putih (Tabel 2). Hal ini membuktikan bahwa kulit batang kayu putih pun mengandung zat alelopati yang mengakibatkan perakaran kecambah jagung berada pada level rentan terhadap alelopati yang dihasikan oleh kulit kayu putih. Konsentrasi larutan ekstrak kayu putih menunjukkan bahwa konsentrasi $100 \%$ menghasilkan STIpanjang akar paling pendek yang berbeda nyata dengan konsentrasi larutan $20 \%$ (Tabel 2.). Hal ini membuktikan bahwa dari konsentrasi rendah sampai konsentrasi tinggi larutan Kayu Putih memiliki zat alelopati yang memberikan pengaruh negatif terhadap pertumbuhan akar benih Jagung dan mengakibatkan tingkat STI pada level sedang pada semua jenis konsentrasi larutan kayu putih.

Variabel pengamatan terhadap STI bobot kering total tanaman menunjukkan bahwa perlakuan jenis ekstrak daun segar kayu putih $\left(\mathrm{E}_{4}\right)$ menghasilkan STI paling tinggi yang berbeda nyata dengan perlakuan jenis ekstrak serasah $\left(E_{5}\right)$ daun kayu putih (Tabel 2). Hal ini disebabkan oleh zat alelopati yang dihasilkan oleh daun segar lebih tinggi yang mengakibatkan level STI paling tinggi sehingga proses pembongkaran karbohidrat dalam benih jagung menjadi terhambat, yang mengakibatkan benih yang ditanam dalam perlakuan ekstrak daun segar terlihat seolah-olah lebih toleran dibandingkan dengan perlakuan lainnya. Konsentrasi larutan ekstrak kayu putih menunjukkan bahwa konsentrasi $100 \%$ menghasilkan STI bobot kering total kecambah paling berat yang berbeda nyata dengan konsentrasi larutan 20\% (Tabel 2). Hal ini membuktikan bahwa dari konsentrasi rendah sampai konsentrasi tinggi larutan kayu putih memiliki zat alelopati yang memberikan pengaruh negatif terhadap 
berat kering total kecambah jagung dan mengakibatkan tingkat STI pada level sedang pada semua jenis konsentrasi larutan kayu putih.

Tabel 2. STI Vigor Benih Jagung

\begin{tabular}{|c|c|c|c|c|c|c|}
\hline \multirow{3}{*}{$\begin{array}{l}\text { Perlakuan } \\
\text { Jenis Ekstrak }\end{array}$} & \multicolumn{6}{|c|}{ STI Vigor Benih } \\
\hline & \multicolumn{2}{|c|}{ Panjang Plumula } & \multicolumn{2}{|c|}{ Panjang akar } & \multicolumn{2}{|c|}{$\begin{array}{c}\text { Berat Kering } \\
\text { Kecambah }\end{array}$} \\
\hline & & & & & & \\
\hline Akar zona 1 (E1) & $1.169 \mathrm{a}$ & $\mathrm{T}$ & $0.966 \mathrm{bc}$ & M & $1.061 \mathrm{bc}$ & M \\
\hline Akar zona 2 (E2) & $0.802 \mathrm{bc}$ & M & $0.899 \mathrm{bc}$ & M & $1.105 \mathrm{bc}$ & M \\
\hline Kulit batang (E3) & $0.736 \mathrm{~cd}$ & M & $0.581 \mathrm{e}$ & $\mathrm{R}$ & $1.024 \mathrm{bc}$ & M \\
\hline Daun segar (E4) & $0.290 \mathrm{f}$ & $\mathrm{R}$ & $0.663 \mathrm{de}$ & $\mathrm{M}$ & $1.310 \mathrm{a}$ & $\mathrm{T}$ \\
\hline Serasah (E5) & $1.087 \mathrm{a}$ & $\mathrm{T}$ & $1.303 \mathrm{a}$ & M & $0.923 \mathrm{c}$ & $\mathrm{M}$ \\
\hline $\mathrm{E} 1+\mathrm{E} 3+\mathrm{E} 4+\mathrm{E} 5(\mathrm{E} 6)$ & $0.909 \mathrm{~b}$ & AT & $1.033 \mathrm{~b}$ & M & $1.081 \mathrm{bc}$ & M \\
\hline $\mathrm{E} 2+\mathrm{E} 3+\mathrm{E} 4+\mathrm{E} 5(\mathrm{E} 7)$ & $0.624 \mathrm{de}$ & $\mathrm{M}$ & $0.819 \mathrm{~cd}$ & M & $1.150 \mathrm{ab}$ & $\mathrm{M}$ \\
\hline E3+E4+E5 (E8) & $0.508 \mathrm{e}$ & $\mathrm{AR}$ & $0.984 \mathrm{bc}$ & M & $1.032 \mathrm{bc}$ & $\mathrm{M}$ \\
\hline E4+E5 (E9) & $0.458 \mathrm{e}$ & $\mathrm{AR}$ & $1.058 \mathrm{~b}$ & M & $1.111 \mathrm{bc}$ & $\mathrm{M}$ \\
\hline \multicolumn{7}{|l|}{ Konsentrasi Larutan } \\
\hline $20 \%$ ekstrak : $80 \%$ aquades $(\mathrm{K} 1)$ & $0.892 \mathrm{a}$ & $\mathrm{M}$ & $0.999 \mathrm{a}$ & M & $0.983 \mathrm{~b}$ & M \\
\hline $40 \%$ ekstrak : $60 \%$ aquades (K2) & $0.759 \mathrm{~b}$ & M & $1.024 \mathrm{a}$ & $\mathrm{M}$ & $1.069 \mathrm{ab}$ & $\mathrm{M}$ \\
\hline $60 \%$ ekstrak : $4 \%$ aquades (K3) & $0.713 \mathrm{bc}$ & $\mathrm{M}$ & $0.965 \mathrm{ab}$ & M & $1.117 \mathrm{ab}$ & M \\
\hline $80 \%$ ekstrak : $2 \%$ aquades (K4) & $0.703 \mathrm{bc}$ & M & $0.803 \mathrm{cb}$ & M & $1.134 \mathrm{a}$ & M \\
\hline $100 \%$ ekstrak : $0 \%$ aquades $(\mathrm{K} 5)$ & $0.592 \mathrm{c}$ & $\mathrm{M}$ & $0.824 \mathrm{c}$ & $\mathrm{M}$ & $1.139 \mathrm{a}$ & $\mathrm{M}$ \\
\hline Interakasi & $(-)$ & & $(-)$ & & $(-)$ & \\
\hline
\end{tabular}

Keterangan : Angka yang diikuti oleh huruf yang sama pada kolom yang sama tidak berbeda nyata pada uji DMRT $\alpha=0,05$; (-) : Tidak Terjadi interaksi; T: toleran, $A T$ Agak Toleran, M: Moderat (sedang), AR: Agak Rentan, R: rentan

Zat alelopati yang dihasilkan oleh tanaman kayu putih memberikan pengaruh negatif terhadap perkecambahan benih jagung disesuaikan dengan bagian dari tanaman. Bagian tanaman kayu putih diatas tanah lebih banyak mempengaruhi pertumbuhan plumula, dan bagian bawah tanah mempengaruhi pertumbuhan akar kecambah. Kecambah jagung tahan terhadap alelopati yang dilepaskan oleh serasah kayu putih baik pada pertumbuhan plumula maupun pertumbuhan akar kecambah. STI pada plumula kecambah jagung lebih banyak dipengaruhi oleh zat alelopat yang dilepaskan oleh daun segar kayu putih sedangkan STI pada panjang akar jagung dipengaruhi oleh perakaran pada zona 1, perakaran zona 2 dan juga kulit batang tanaman kayu putih. Ha ini disebabkan oleh daun tanaman kayu putih lebih banyak mengandung minyak esensial dan zat-zat yang berasal dari turunan fenolik yang berperan untuk menghambat perkembangan tajuk tanaman sasaran. Sedangkan akar zona 1, akar zona 2 dan kulit batang tanaman lebih berperan untuk menghambat pertumbuhan akar tanaman sasaran. Junaedi et.al., (2006) bahwa senyawa metabolit sekunder seperti fenolik, terpenoid, alkaloid, steroid, poliasetilena, dan minyak esensial dilaporkan memiliki aktivitas alelopati.

Tanaman kayu putih menghambat pertumbuhan kecambah melalui dua arah yang berbeda yaitu menghambat pertumbuhan tajuk dan menghambat pertumbuhan akar. Pertumbuhan akar yang terhambat menyebabkan serapan tanaman terhadap sumberdaya menjadi lebih rendah sehingga fisiologi tanaman menjadi terganggu khususnya ganguan pada bukaan stomata pada daun dan proses fotosintesi. Hambatan berikutnya yang terjadi dalam proses sintesis protein, pigmen dan senyawa karbon lain, serta aktivitas beberapa fitohormon. Sebagian atau seluruh hambatan tersebut kemudian bermuara pada terganggunya pembelahan dan pembesaran sel yang akhirnya menghambat pertumbuhan dan perkembangan tumbuhan sasaran (Nandito, 2006).

\section{Simpulan}

Berdasarkan hasil dan pembahasan yang dilakukan, maka dapat disimpulkan bahwa tidak terjadi interaksi antara perlakuan bagian dan persentase ekstrak kayu putih terhadap perkecambahan benih jagung dengan kandungan Alelopati paling tinggi dihasilkan oleh bagian daun segar kayu putih dan menyebabkan kecambah jagung berada pada level rentan dalam tingkat stress tolerance index dibandingkan dengan serasah daun kayu putih. Persentase ekstrak kayu putih dari level rendah sampai paling tinggi mengandung alelopati dan menyebabkan tingkat kecambah jagung berada pada level moderat dalam tingkat stress tolerance index serta seluruh bagian organ segar tanaman kayu putih pada berbagai konsentrasi mampu menghambat pertumbuhan dan perkembangan kecambah dan menempatkan kecambah Jagung pada level moderat sampai rentan dalam pengelompokan stress tolerance index.

\section{Pustaka}

Chung, I., Miller, D. A. 1995. Differences in Autotoxicity among Seven Alfalfa Cultivars. Agron. J. 87:596-600 p.

Soltys, D., U., Bogatek, R., Gniazdowska, A. 2013. Allelochemicals as Bioherbicides - Present and Perspectives. INTECH (diakses 24 Mei 2014).

Djazuli, M., Sukamto. 2011. Teknologi Pengendalian Alelopati Pada Sentra Produksi Nilam. Laporan Teknis Penelitian Tahun Anggaran 2011 Balai Penelitian Tanaman Rempah dan Obat. (diakses 18 september 2014).

Djazuli, M. 2011. Potensi Senyawa Alelopati Sebagai Herbisida Nabati Alternatif Pada Budidaya Lada Organik. Penelitian Tanaman Obat dan Aromatik. (diakses 20 Juli 2014).
Fallah, A.F. 2006. Perspektif Pertanian Dalam Lingkungan Yang Terkontrol. (diakses 15 Agustus 2015).

Fernandes, G.C. J. 1993. Effective Selection Criteria For Assessing Plant Stress Tolerance. Nevada: Department of Agricultural Economics, University of Nevada-Reno

Gomez, K.A.,Gomez, A.A. 1984. Statistical Procedures for Agricultural Research.John Wiley \& Sons.

Junaidi, A.B., Yunus, R. 2009. Kajian Potensi Tumbuhan Gelam (Melaleuca cajuputi Powell) untuk Bahan Baku Industri Pulp. Jurnal Hutan Tropis Vol 10 (28)

Junaedi, A. Muhamad, A.C.,Ho Kim, K. 2006. Ulasan Terkini Kajian Alelopati. Jurnal Hayati 13 (02). Diakses 15 agustus 2015

Kurniasih, B. 2002.Sifat Perakaran Beberapa Varietas Padi Gogo Dalam Cekaman Residu Alelopati Gulma. Agrivita 24(02):89-95.

Nandito. 2006.Alelopati - Interaksi antar populasi. Diakses juli 2014.

Pramiadi, D., Suyitno A. L. 2008. Uji Daya Alelopati Ekstrak Daun Kleresede (Gliricidia sp) Melalui Bioassay Perkecambahan dengan Biji Sawi (Brassica sp) dan Biji bayam (Amaranthus sp), Makalah dipresentasikan dalam Seminar Nasional dalam rangka Dies UNY ke 44 di FPMIPA - UNY diakses 15 Agustus 2015.

Rahim, A.A. 2010.Chemical Composition, Total Phenolic Content And Radical Scavenging Activity Of Melaleuca Cajuputi Powell Essential Oils., Bachelor of science (hons.). Chemistry Faculty of Applied Sciences Universiti Teknologi Mara: Diakses 5 Agustus 2014.

Setyowati, N., Simarmata, M., Yanuarti, S. 1999. Respon Perkecambahan Beberapa Tanaman Pangan Dan Hortikultura Terhadap Alelopati Teki (Cyperus Rotundus L.). Agrotropika IV(1):37-41.

Solichatun.2000. Alelopati Ekstrak Kacang Hijau (Vigna radiata (L.)Wilczek) terhadap Perkecambahan Kedelai (Glycine max Merr.). BioSMART 2(02):31-36.

Togatorop, D. A., Setyowati, N., Nurjanah, U. 2010. Studi alelopati Widelia trilobata, Ageratum conyzoides, Chromolaena odorata dan Mikania micrantha terhadap pertumbuhan dan hasil sawi.Bengkulu: Prosiding Seminar Nasional dan Rapat Tahunan Dekan Bidang Ilmu-Ilmu Pertanian 23-25 Mei 2010.

Fitria, Y. 2011. Pengaruh Alelopati Gulma Cyperus Rotundus, Ageratum Conyzoides Dan Digitaria Adscendens Terhadap Pertumbuhan Dan Produksi Tanaman Tomat (Lycopersicon Esculentum Mill.). Bogor: Fakultas Pertanian IPB.

Hafsah, S., Abduh, M. U., Cut M. N. 2012. Efek Alelopati Ageratum Conyzoides Terhadap Pertumbuhan Sawi. J. Floratek 8: 18-24. 